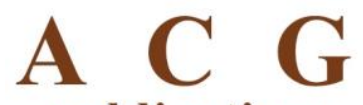

publications

Org. Commun. 14:1 (2021) 81-91

organic

communications

\title{
Knoevenagel condensation reaction catalysed by agro-waste extract as a greener solvent catalyst
}

\author{
Krishnappa B. Badiger $\odot$ and Kantharaju Kamanna \\ Peptide and Medicinal Chemistry Research Laboratory, Department of Chemistry, Rani Channamma \\ University, P-B, NH-4, Belagavi 591 156, India
}

(Received January 22, 2021; Revised March 15, 2021; Accepted March 18, 2021)

\begin{abstract}
This paper present a novel Knoevenagel reaction protocol for the condensation of aromatic/heteroaromatic aldehydes with malononitrile to give $\alpha, \beta$-unsaturated benzylidene derivatives. The main focus of this work is to reveal the usability of agro-waste extracts as a catalyst in the Knoevenagel condensation. The present protocol proceeds efficiently for various substituted aromatic and heterocyclic aldehydes in the Knoevenagel reactions. In addition, the present method describes direct isolation of the formed products without using organic solvent extraction gave good yields product.
\end{abstract}

Keywords: one-pot reaction; green chemistry; solvent-free; Knoevenagel condensation reaction; malononitrile; room temperature. O2021 ACG Publication. All right reserved.

\section{Introduction}

The carbon-carbon bond formation via Knoevenagel condensation ${ }^{1-3}$ is one of the most important routes repeated in the synthetic organic chemistry and allows the production of various active pharmaceutical molecules. ${ }^{4}$<smiles>N#CC(C#N)=Cc1ccc([N+](=O)[O-])cc1</smiles>

1<smiles>COc1cc(C=C(C#N)C#N)cc(OC)c1OC</smiles>

2<smiles>N#CC(C#N)=Cc1ccc(O)c(O)c1</smiles>

3

Figure 1. Structure of biologically potent benzylidinemalononitrile derivatives

\footnotetext{
*Corresponding author:E-Mail: kk@rcub.ac.in
} 
Knoevenagel condensation reaction catalysed by agro-waste extract

The arylidinemalononitrile derivatives allowed to achieve diverse pharmaceutically potent compound such as 2-(4-nitrobenzylidene)malononitrile (1) and 2-(3,4,5-trimethoxybenzylidene)malononitrile (2) well known potential tyrosine kinase inhibitors ${ }^{12}, 2$-(3,4-dihydroxybenzylidene)malononitrile derivative (3) emerged as a efficient anti-melanogenic agent. Many molecules derived from Knoevenagel condensation are well documented (Figure 1). ${ }^{13}$

Knoevenagel condensation are usually carried out by the reactions of active methylene compound with aliphatic or aromatic or heterocyclic aldehyde in the presence of organic base as a catalyst. Due to environment friendly concerns, the use of a organic base is not desirable and should be replaced. Therefore, synthetic organic chemists developed various inorganic metal and metal oxide derivatives heterogeneous catalyst with reusable such as $\mathrm{AlPO}_{4} \cdot \mathrm{Al}_{2} \mathrm{O}_{3}{ }^{18}$, USY Zeolite ${ }^{20}, \mathrm{MgBr}_{2}$. $\mathrm{OEt}_{2}{ }^{21}, \mathrm{CTMAB}^{22}$, $\mathrm{H}_{3} \mathrm{PWO}_{40}{ }^{23}, \mathrm{I}_{2} / \mathrm{K}_{2} \mathrm{CO}_{3}^{24}$, [MeHMTA] $\mathrm{BF}_{4}$ ionic liquid ${ }^{25}$ and $\mathrm{LaCl}_{3} \cdot \mathrm{H}_{2} \mathrm{O}^{26}$.

The use of greener solvent and catalyst such as ionic liquids are alternative method is well documented ${ }^{14}$, because of their good solubility, non-flammability, less vaporization and recyclability. ${ }^{25}$ However, their application is limited in the macroscale process of the products due to their expensive reagents costs. Another method for Knoevenagel condensation was reported solvent-free condition, which lead environmentally benign, cost effective and gave high yield ${ }^{18}$. The current trend of synthetic organic chemistry is to develop Knoevenagel reaction under greener solvent, which should be environmentally friendly, cost effective, simple operation and efficient. In this context, water as a solvent and many agro-waste derived catalysts were reported by various research group, Water extract of nilgiri bark ash ${ }^{9}$, water extract of papaya bark $\operatorname{ash}^{14}$, Pineapple juice ${ }^{34}$, Water extract of banana ${ }^{45}$ and Water extract of lemon fruit shell ash $^{53}$. Although microwave-accelerated reactions are reported robust and faster method, there are also limitation on scalability, compatibility and energy usage ${ }^{7}$.

In this study, we have demonstrated a possibility to carry out Knoevenagel reaction of aromatic aldehydes or heterocyclic aldehyde with malononitrile catalyzed agro-waste extract, which served as an environmentally benign catalyst solvent. After completion of the reaction, the reaction mixture filtered to give pure Knoevenagel product in high yields with purity. Furthermore, this study explored the tolerability of the substituents on benzene ring and heterocycles.

\section{Experimental}

\subsection{Material and Methods}

FT-IR spectra were recorded in $\mathrm{KBr}$ disk on a Shimadzu FT-IR, ${ }^{1} \mathrm{H}$ and ${ }^{13} \mathrm{C}-\mathrm{NMR}$ spectra obtained using a Bruker Avance $300 \mathrm{MHz}$ spectrometer (DRX). LC-MS spectra recorded in Waters synapt G2 high detection mass spectrometry. The progress of the reaction was monitored by TLC. Melting point of the final product was determined in open capillaries and are uncorrected.

\subsection{Preparation of WEOFPA}

We are adopted our recently developed preparation of Water Extract of Orange Fruit Peel Ash (WEOFPA). Briefly, orange fruits are collected from a local fruit market in Belagavi, India. The outer shell is taken out, washed with tap water, and followed washed with double-distilled water to remove any physical impurities on the surface, it was dreid under sunlight and thermal treatment on Bunsen burner (manuscript submitted) to ash. The obtained ash $10 \mathrm{~g}$ was suspended in $100 \mathrm{~mL}$ of double distilled water and stirred for an hour at room temperature. The suspension was filtered and light brown coloured filtrate is named as a WEOFPA.

\subsection{Experimental Procedure for the Synthesis of Arylidinemalononitrile Derivatives (3a-3p)}

A mixture of aromatic aldehyde (1 mmole), malononitrile (1mmole) and $3 \mathrm{~mL}$ of WEOFPA taken in a $50 \mathrm{~mL}$ round bottom flask, and reaction mixture stirred at room temperature, the reaction progress was monitored by TLC. After the reaction completion, ice cold water $(10 \mathrm{~mL})$ was added to reaction mixture, and product was collected by simple filtration, washed with water several times and dried to yield title compounds (3a-3p) as a solid. The product was obtained after recrystallization, and confirmed by FT-IR, ${ }^{1} \mathrm{H},{ }^{13} \mathrm{C}-\mathrm{NMR}$ and mass spectrometry. The melting point of the obtained products very much comparable with the literature reported. 


\subsection{Spectral Data of Representative Selected Compounds}

2- Benzylidenemalononitrile $(3 a): R_{\mathrm{f}}=0.56$ (7:3 hexane-ethyl acetate); white solid; m.p. $81^{\circ} \mathrm{C}\left(\mathrm{lit}^{34} .82\right.$ -<smiles>N#CC(C#N)=Cc1ccccc1</smiles$\left.84^{\circ} \mathrm{C}\right): 93 \%$. FT-IR $\left(\mathrm{KBr}, \mathrm{cm}^{-1}\right): 2223(\mathrm{CN}), 1568(\mathrm{C}=\mathrm{C}) ;{ }^{1} \mathrm{H}-\mathrm{NMR}\left(\mathrm{CDCl}_{3}\right): \delta(\mathrm{ppm})$ $7.88(\mathrm{~d}, \quad J=7.05 \mathrm{~Hz}, 2 \mathrm{H}), 7.76(\mathrm{~s}, 1 \mathrm{H}), 7.61(\mathrm{t}, J=7.6 \mathrm{~Hz}, 2 \mathrm{H}) ;{ }^{13} \mathrm{C}-\mathrm{NMR}\left(\mathrm{CDCl}_{3}\right)$ : $\delta(\mathrm{ppm}): 159.9,134.5,131.0,130.5,129.5,113.8,112.5,82.8$; LC-MS: $m / z$ found: 154.05 $[\mathrm{M}+\mathrm{H}]^{+} \mathrm{C}_{10} \mathrm{H}_{6} \mathrm{~N}_{2}$ Calcd.: 155.06 .

2-(2-Hydroxybenzylidene) malononitrile $(3 \boldsymbol{b}): R_{\mathrm{f}}=0.64$ (7:3 hexane-ethyl acetate); light yellow solid; m.p. $160^{\circ} \mathrm{C}\left(\mathrm{lit}^{27} .159-161^{\circ} \mathrm{C}\right) ; 90 \%$ yield: FT-IR $\left(\mathrm{KBr}, \mathrm{cm}^{-1}\right)$ : $3552(-\mathrm{OH}), 2228(\mathrm{CN})$,<smiles>N#CC(C#N)=Cc1ccccc1O</smiles>
$1607(\mathrm{C}=\mathrm{C}), 791(-\mathrm{C}-\mathrm{H}) .{ }^{1} \mathrm{H}-\mathrm{NMR}\left(\mathrm{CMSO}-\mathrm{d}_{6}\right): \delta(\mathrm{ppm})$ 5.80-7.50 (m, 4H), $7.55(\mathrm{~s}, 1 \mathrm{H}$, $\mathrm{Ar}-\mathrm{OH}), 5.85(\mathrm{~s}, 1 \mathrm{H}) ;{ }^{13} \mathrm{C}-\mathrm{NMR}\left(\mathrm{CDCl}_{3}\right): \delta(\mathrm{ppm}) 115.7,116.1,116.4,124.8,125.29$, 129.60, 154.7, 162.5. Please check LC-MS: $m / z$ found: $170.05[\mathrm{M}+\mathrm{H}]^{+} \mathrm{C}_{10} \mathrm{H}_{6} \mathrm{~N}_{2} \mathrm{O}$ Calcd.:171.05.

2-(Naphthalen-1-ylmethylene) malononitrile $(3 \mathrm{l}): R_{\mathrm{f}}=0.72$ (7:3 hexane-ethyl acetate); yellow powder solid; m.p. $172^{\circ} \mathrm{C}\left(\mathrm{lit}^{54} .172-174^{\circ} \mathrm{C}\right) ; 90 \%$ yield: FT-IR $\left(\mathrm{KBr}, \mathrm{cm}^{-1}\right) ; 3534(-\mathrm{OH})$, $2224(\mathrm{CN}), 1562(\mathrm{C}=\mathrm{C}) ;{ }^{1} \mathrm{H}-\mathrm{NMR}\left(\mathrm{DMSO}-\mathrm{d}_{6}\right): \delta(\mathrm{ppm}): 9.38(\mathrm{~s}, 1 \mathrm{H}, \mathrm{C}-\mathrm{H}), 8.27$<smiles>N#CC(C#N)=Cc1c(O)ccc2ccccc12</smiles>
$(\mathrm{m}, 2 \mathrm{H}, \mathrm{Ar}-\mathrm{H}), 8.20(\mathrm{t}, 1 \mathrm{H}, J=7.2 \mathrm{~Hz}, \mathrm{Ar}-\mathrm{H}), 8.09(\mathrm{t}, 1 \mathrm{H}, J=7.2 \mathrm{~Hz}, \mathrm{ArH}), 7.70$ $(\mathrm{m}, 3 \mathrm{H}, \mathrm{Ar}-\mathrm{H}) .{ }^{13} \mathrm{C}-\mathrm{NMR}\left(\mathrm{DMSO}-\mathrm{d}_{6}\right): \delta(\mathrm{ppm}) 157.6,134.8,133.4,131.0,129.3$, $128.5,128.7,127.4,125.3,124.3,122.2,113.6,112.4,85.1$, LC-MS: $\mathrm{m} / \mathrm{z}$ found: 204.1[M+H] $]^{+}, \mathrm{C}_{14} \mathrm{H}_{8} \mathrm{~N}_{2}$ Calcd.: 204.0.

2-(2-Furfurylmethylene) malononitrile $(3 \mathbf{m}): R_{\mathrm{f}}=0.59$ (7:3 hexane-ethyl acetate); black solid; m.p. $64^{\circ} \mathrm{C}$ (lit $\left.{ }^{34} .65-66^{\circ} \mathrm{C}\right) ; 92 \%$ yield: FT-IR $\left(\mathrm{KBr} \mathrm{cm}^{-1}\right)$ : $1455(\mathrm{C}=\mathrm{C}), 1743$ (furfuryl), 2235 $(\mathrm{CN}) ;{ }^{1} \mathrm{H}$ NMR $\left(\mathrm{CDCl}_{3}\right) \delta(\mathrm{ppm})$ : 6.87-6.88 $(\mathrm{m}, 1 \mathrm{H}$, furfuryl $), 7.09(\mathrm{~m}, 1 \mathrm{H}$, furfuryl), $7.19(\mathrm{~s}, 1 \mathrm{H}, \mathrm{CH}=\mathrm{C}), 7.45\left(\mathrm{~s}, 1 \mathrm{H}\right.$, furfuryl); ${ }^{13} \mathrm{C}-\mathrm{NMR}\left(\mathrm{CDCl}_{3}\right): \delta(\mathrm{ppm}) 75.46,113.89$, 115.11, 115.37, 126.44, 145.02, 148.60, 151.80. LC-MS: $\mathrm{m} / \mathrm{z}$ found: $144.03[\mathrm{M}+\mathrm{H}]^{+}$, $\mathrm{C}_{8} \mathrm{H}_{4} \mathrm{~N}_{2} \mathrm{O}$ Calcd.:145.04.

2-(Pyridin-4-ylmethylene) malononitrile (3n): $R_{\mathrm{f}}=0.70$ (7:3 hexane-ethyl acetate); white solid; CN m.p. $102^{\circ} \mathrm{C}\left(\operatorname{lit}^{16} .100-102^{\circ} \mathrm{C}\right) ; 90 \%$ yield. FT-IR: $3023(\mathrm{HC}=\mathrm{C}), 2233(\mathrm{CN}), 1610,1548$ $(\mathrm{C}=\mathrm{C}), 1403(\mathrm{C}-\mathrm{N}) ;{ }^{1} \mathrm{H}$ NMR (DMSO-d $\left.{ }_{6}\right) \delta(\mathrm{ppm}): 7.69(\mathrm{~d}, J=5.3 \mathrm{~Hz} 2 \mathrm{H} \mathrm{ArH}), 7.83(\mathrm{~s}$ $1 \mathrm{H}$ vinyl $\mathrm{H}), 8.88(\mathrm{~d}, J=5.3 \mathrm{~Hz}, 2 \mathrm{H} \mathrm{Ar}-\mathrm{H}) ;{ }^{13} \mathrm{C} \mathrm{NMR}\left(\mathrm{CDCl}_{3}\right): 89.0,111.8,112.9,123.1$, 137.4, 151.9, 158.0. LC-MS: $m / z$ found: $155.05[\mathrm{M}+\mathrm{H}]^{+}, \mathrm{C}_{9} \mathrm{H}_{5} \mathrm{~N}_{3}$ Calcd.:156.05.

2-((1H-Indol-3-yl) methylene) malononitrile $(3): R_{\mathrm{f}}=0.79$ (7:3 hexane-ethyl acetate); Yellow solid; m.p,<smiles>N#CC(C#N)=Cc1c[nH]c2ccccc12</smiles>
$190^{\circ} \mathrm{C}\left(\mathrm{lit}^{15} .187-189{ }^{\circ} \mathrm{C}\right) ; 89 \%$. FT-IR $\left(\mathrm{KBr} \mathrm{cm}^{-1}\right): 3270(\mathrm{~N}-\mathrm{H}), \quad 2915(=\mathrm{C}-\mathrm{H})$, 2215(CN), 1566(C=C), 1336(C-N); ${ }^{1} \mathrm{H}$ NMR $\left(\right.$ DMSO-d $\left._{6}\right), 7.31(\mathrm{t}, 1 \mathrm{H}, 7.65 \mathrm{~Hz})$, $7.36(\mathrm{t}, 1 \mathrm{H}, J=7.23), 7.54(\mathrm{~d}, 1 \mathrm{H}, J=8 \mathrm{~Hz}), 7.92(\mathrm{~d}, 1 \mathrm{H}, J=8 \mathrm{~Hz}), 8.52(\mathrm{~d}, 1 \mathrm{H}, J=3.6$ $\mathrm{Hz}), 9.14(\mathrm{~s}, 1 \mathrm{H}), 11.2(\mathrm{~d}, 1 \mathrm{H}, J=11.0 \mathrm{~Hz}) ;{ }^{13} \mathrm{C}$ NMR (DMSO-d 6 ): $73.45,110.24$, $112.45(2 \mathrm{CN}), 115.24,118.70,122.40,123.45,128.63,135.6,137.01,150.48$; LCMS: $m / z$ found: $193[\mathrm{M}+\mathrm{H}]^{+}, \mathrm{C}_{12} \mathrm{H}_{7} \mathrm{~N}_{3}$ Calcd.: 194.6. 
Knoevenagel condensation reaction catalysed by agro-waste extract

\section{Result and Discussion}

Knoevenagel reaction employed organic base, inorganic metal or metal oxides as a catalyst for the formation of a condensed product. Our laboratory initial effort develop a greener protocol "from waste to wealth" concept, which was demonstrated in numerous heterocyclic synthesis catalyzed by agro-waste extracts ${ }^{9,14,34,45,53}$. To start the required catalytic media for the present work, we have collected orange fruits peel from the local market available and subjected to thermal treatment. The resulted ash was treated with double distilled water to obtain water extract of orange fruit peel ash is named as WEOFPA (manuscript submitted for the publication).

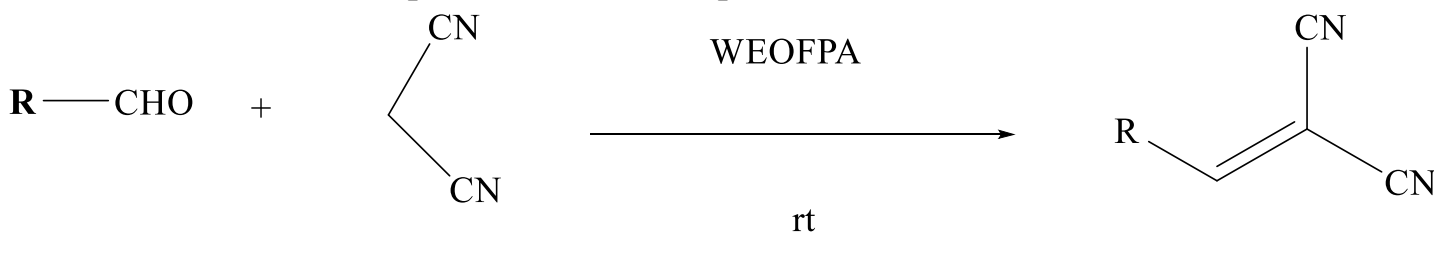

1<smiles>[R][N+]([O-])([O-])c1ccccc1</smiles>

2<smiles>Cc1ccccc1O</smiles><smiles>O=[N+]([O-])c1ccco1</smiles><smiles>COc1ccncc1</smiles><smiles>Cc1c[nH]c2ccccc12</smiles>

Scheme 1. General reaction of Knoevenagel condensation reaction

The extracted solution $\mathrm{pH}$ was examined and found to be 11.7. The ash powder was examined by elemental analysis using XRD, SEM-EDX and flame photometry. The elemental composition present in extract was found rich in $\mathrm{Na}, \mathrm{K}, \mathrm{Ca}, \mathrm{Mg}$ and minor contents of $\mathrm{Si}, \mathrm{Ni}, \mathrm{Fe}$ etc. Overall the solution containing rich of potassium and sodium carbonate, and hydroxides of other elements make the solution basic in nature. To explore the utility of the prepared extract, we selected a model Knoevenagel condensation raection using benzaldehyde with malononitrile at room temperature (Scheme 1) stirring condition for about $45 \mathrm{~min}$ gave a solid product isolation, and separated by filteration and purified by recrystallization.

To optimize the amount of WEOFPA volume required for the reaction for 1 mmole scale, we started use of different volumes of $0,1,2,3,4$ and $5 \mathrm{~mL}$ of WEOFPA in a model reaction examination at room temperature. The optimization studies revealed that, the gradual increase in the product isolation occurs between 0-3 mL volumes of WEOFPA. Further use of catalyst volume 4 and $5 \mathrm{~mL}$, did not see any increase of the product yield. This optimization reaction revealed optimal volume of WEOFPA required for the Knoevenagel reaction is $3 \mathrm{~mL}$ at room temperature stirring condition (Table 1).

Table 1. Optimization of WEOFPA volume

\begin{tabular}{cccc} 
S. No. & Volume $(\mathbf{m L})$ & Reaction time $(\mathbf{m i n})$ & Yield $(\boldsymbol{\%})$ \\
\hline 1 & 0 & 60 & $60^{*}$ \\
2 & 1 & 55 & 70 \\
3 & 2 & 50 & 75 \\
4 & 3 & 45 & 90 \\
5 & 4 & 45 & 90 \\
6 & 5 & 45 & 90 \\
\hline
\end{tabular}

S.No.1, reaction performed without catalyst, but gave less yield with long reaction time. 
Badiger and Kantharaju, Org. Commun. (2021) 14:1 81-91

Table 2. Physical constant and reaction data of Knoevenagel product.

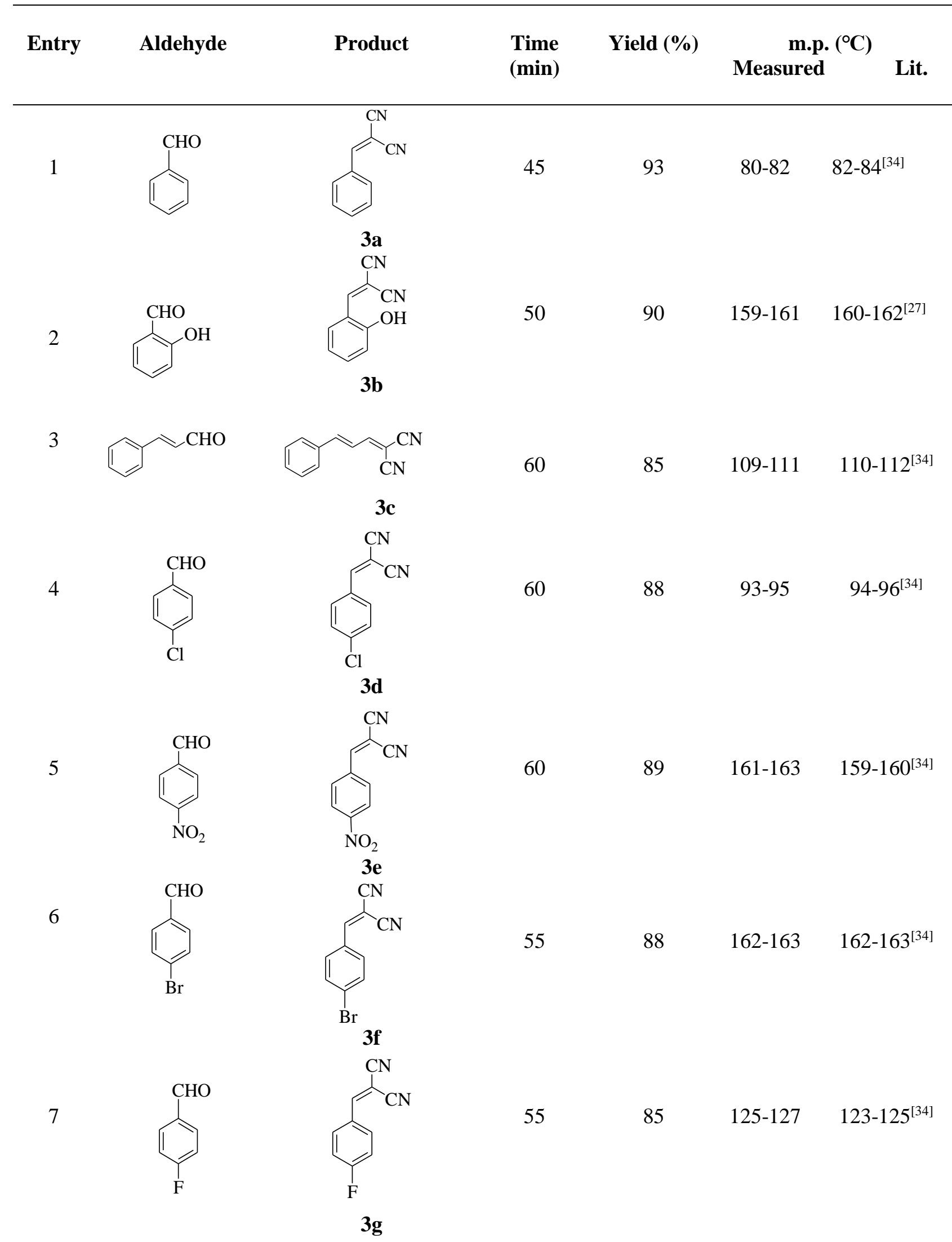


Knoevenagel condensation reaction catalysed by agro-waste extract

Table 2 continued.

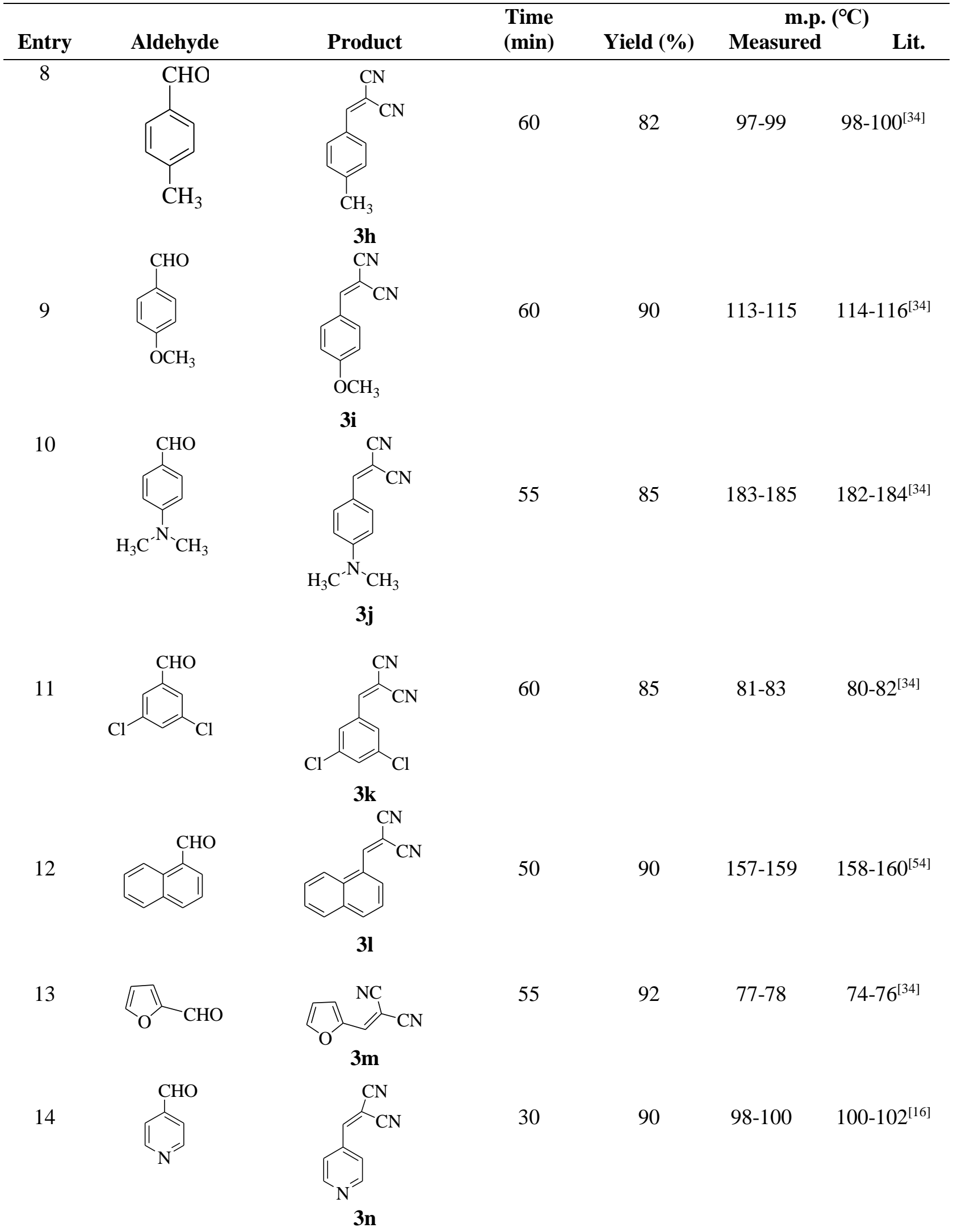


Table 2 continued.

\begin{tabular}{lllllll}
\hline Entry & Aldehyde & Product & $\begin{array}{c}\text { Time } \\
(\text { min) }\end{array}$ & Yield (\%) & $\begin{array}{c}\text { m.p. }\left({ }^{\circ} \mathbf{C}\right) \\
\text { Measured }\end{array}$ & Lit. \\
\hline
\end{tabular}

- $\quad$ All the products were characterized by FT-IR, ${ }^{1} \mathrm{H}$ and ${ }^{13} \mathrm{C}-\mathrm{NMR}$ and LC-MS

- Yields refer to the isolated yields.

Table 3. Comparison of different catalysts reported for the synthesis of arylidinemalononitrile derivatives.

\begin{tabular}{|c|c|c|c|c|c|c|}
\hline S. No. & Catalyst & Solvent & Time (min) & Reaction condition & Yield (\%) & Reference \\
\hline 1 & $\mathrm{AlPO}_{4} \cdot \mathrm{Al}_{2} \mathrm{O}_{3}$ & - & 30 & $\mathrm{rt}$ & 88 & 18 \\
\hline 2 & USY Zeolite & Benzene & $12 \mathrm{hr}$ & reflux & 92 & 20 \\
\hline 3 & $\mathrm{MgBr}_{2} \cdot \mathrm{OEt}_{2}$ & THF & $1-2 \mathrm{hr}$ & $\mathrm{rt}$ & 98 & 21 \\
\hline 4 & СТМАВ & Water & $1.5 \mathrm{hr}$ & $\mathrm{rt}$ & 90.6 & 22 \\
\hline 5 & $\mathrm{H}_{3} \mathrm{PWO}_{40}$ & Water & 15 & reflux & 91 & 23 \\
\hline 6 & $\mathrm{I}_{2} / \mathrm{K}_{2} \mathrm{CO}_{3}$ & EtOH/DMF & $12 \mathrm{hr}$ & $\mathrm{rt}$ & 80 & 24 \\
\hline 7 & $\begin{array}{c}\mathrm{MeHMTA}_{\mathrm{B} \mathrm{BF}_{4} \text { ionic }} \\
\text { liquid }\end{array}$ & water & 15 & $\mathrm{rt}$ & 99 & 25 \\
\hline 8 & $\mathrm{LaCl}_{3} \cdot \mathrm{H}_{2} \mathrm{O}$ & - & $1 \mathrm{hr}$ & Heated at $80^{\circ}$ & 95 & 26 \\
\hline 9 & $\begin{array}{c}\mathrm{SO}_{4}^{-2} \text { ion promoted } \\
\mathrm{ZrO}_{4}\end{array}$ & $\mathrm{~N}_{2}$ atm, & $180 \mathrm{~min}$ & reflux & 89 & 28 \\
\hline 10 & $\mathrm{Fe}_{2}\left(\mathrm{SO}_{4}\right)_{3}$ & DCM, & $20 \min$ & $\mathrm{rt}$ & 93 & 29 \\
\hline 11 & $\mathrm{SiO}_{2}-\mathrm{NH}_{4} \mathrm{OAc}$ & DCM, & $7 \mathrm{hr}$ & $60^{\circ} \mathrm{C}$ & 87 & 30 \\
\hline 12 & ${\mathrm{MOF}-\mathrm{RNH}_{2}}_{2}$ & Toluene, & $2 \mathrm{hr}$ & $\mathrm{rt}$ & 99 & 31 \\
\hline 13 & $\mathrm{GaCl}_{3}$ & - & $2 \min$ & Neat, grinding & 98 & 32 \\
\hline 14 & Piperidine & - & $6 \mathrm{hr}$ & reflux & 94 & 33 \\
\hline 15 & Pineapple juice & - & $1.5 \mathrm{hr}$ & $\mathrm{rt}$ & 89 & 34 \\
\hline 16 & WEOFPA & Ethanol & $45 \mathrm{~min}$ & rt & 90 & $\begin{array}{l}\text { Present } \\
\text { Work }\end{array}$ \\
\hline
\end{tabular}


Knoevenagel condensation reaction catalysed by agro-waste extract

To explore the scope of the present method for different aldehyde derivatives such as aliphatic, aromatic and heterocyclic aldehydes are studied. No product formation was observed in the reaction of acetaldehyde with malononitrile for 1 mmole scale using $3 \mathrm{~mL}$ catalyst. However, the same reaction condition of benzaldehyde derivatives or heterocyclic aldehydes with malononitrile resulted high yield of condensation product isolation. Therefore, we can conclude, this method is well suitable for the substituted aromatic aldehyde and heterocyclic aldehyde Knoevenagel condensation (Table 2). Further, we also examined method for the bulk synthesis of Knoevenagel product upto $10 \mathrm{mmol}$ scale reaction in a model reaction, and observed isolation of the product in excellent yield and purity.

We also compared the present method with the reported data in the literature, which is tabulated in Table 3. In the literature substrates 1-13 listed in the Table 3 were carried out Knovenagel reaction in the presence of inorganic composites. These catalysts are expensive and harsh reaction conditions along with longer reaction time reporetd. Further, S. No. 1-13 used hazardous solvents for the reaction. Overall the present method demonstrated simplicity of the reaction condition and use of environmentally benign, less expensive catalyst for the Knoevenagel reaction compared to literature reported.

Several spectroscopic techniques confirmed the structure of the final products 3a-p. For example, the isolated product 3m observed FT-IR using $\mathrm{KBr}$ pellet: $3341.09(\mathrm{CH}-\mathrm{H}), 2195.17$ (C-C triple bond), 1600.11(C=C), 1379.05(C-N), $1191.76(\mathrm{C}-\mathrm{O}-\mathrm{C})$ and $761.87(\mathrm{C}-\mathrm{H}) .{ }^{1} \mathrm{H}$ NMR spectrum shows proton variation at 6.87-6.89 (m, $\mathrm{H}$ of furfuryl), $7.41(\mathrm{~m}, 1 \mathrm{H}$, furfuryl $), 7.44(\mathrm{~s}, 1 \mathrm{H}, \mathrm{CH}=\mathrm{C}), 8.26$ (s, 1H, furfuryl). ${ }^{13} \mathrm{C}$ NMR: $\delta$ : $151.80(\mathrm{C}=\mathrm{C}, 2$-furan), 148.60 (C-C), 145.02 (ethylene -C), 115.37(nitrile- $-\mathrm{C}=\mathrm{C}$ ), 115.11(nitrile $-\mathrm{C}=\mathrm{C}$ ), 113.81(2-furan $-\mathrm{C}=\mathrm{C}$ ), 75.46 (1-ethylene). Mass spectrometry data is observed using LC-MS, which gives strong $\mathrm{m} / \mathrm{z}$ peak at $144.03[\mathrm{M}+\mathrm{H}]^{+}$and theoretically $\left(\mathrm{C}_{8} \mathrm{H}_{4} \mathrm{~N}_{2} \mathrm{O}\right): 145.04$.

\section{Conclusion}

In summary, we have demonstrated a new green protocol for Knoevenagel condensation catalysed by agro-waste extract as a catalytic media via "waste to wealth" concept. The method used agro-waste extract as a catalyst provides efficient application of the reaction with no use of the organic solvents and gives pure final product in good to excellent yields. Further, the reaction can be applied to heterocyclic aldehydes. Thus, an eco-friendly and economic method has been developed for Knoevenagel condensation of aromatic aldehydes and malononitrile to give good yields. The catalyst plays dual role either catalyst or solvent. The reaction procedure does not use any toxic materials to environment, therefore, it as a green approach. This procedure offers more advantages including shorter reaction time, clean reactions, and easy work-up.

\section{Acknowledgement}

Authors are thankful to the UGC for the award of Major Research Project (UGCMRP:F.43-181/2014(SR)\} and VGST, Govt. of Karnataka for SMYSR award to Dr. KK. The authors also acknowledges the Department of Science and Technology for the award of DST-FIST programme to the Department of Chemistry, RCUB.

\section{Supporting Information}

Supporting information accompanies this paper on http://www.acgpubs.org/journal/organiccommunications

\section{ORCID}

Krishnappa B Badiger :0000-0001-5808-3273

Kantharaju Kamanna: 0000-0002-4696-5401 
Badiger and Kantharaju, Org. Commun. (2021) 14:1 81-91

\section{References}

[1] Knoevanagel, E. Condensation von malonsäuremitaromatischen aldehyden durch ammoniakund amine. Ber. Deut. Chem. Ges. 1898, 31, 2596-2619.

[2] Debache, A.; Boulcina, R.; Belfaitah, A.; Rhouati, S.; Carboni, B. One-pot synthesis of 1,4dihydropyridines via a phenylboronic acid catalyzed hantzsch three-component reaction. Synlett 2008, 509-512.

[3] Calter, M.A.; Phillips, R.M.; Flaschenriem, C. Catalytic, asymmetric, "interrupted" feist- Bénary Reactions. J. Am. Chem. Soc. 2005, 127, 14566-14567.

[4] Umair, A. K.; Imran, A. H.; Abdul,W.; Muneera, N. B.; Shoaib, M.; Syed, K. A.; Firdous,I. A.; Synthesis of a-cyanoacrylates through knoevenagel condensation under solvent free conditions and their antimicrobial activity. Int. J. Curr. Res. 2015, 7,13808-13811.

[5] RichaKhare, J.; Pandey.; Smritiand Ruchi Rupanwar. The Importance and Applications of Knoevenagel Reaction (Brief Review), OJCHEG. 2019, 35(1), 423-429.

[6] Jack van Schijndel,; Luiz Alberto Canalle,; Dennis Molendijk,; Jan Meuldijk, The green Knoevenagel condensation: solvent-free condensation of benzaldehydes. Green Chem. Lett. Rev. 2017, 10(4). 404-411.

[7] Siham Mallouk,; Khalid Bougrin,; Abdelaziz Laghzizil,; Rachid Benhida. Microwave-assisted and efficient solvent-free Knoevenagel condensation. A sustainable protocol using porous calcium hydroxyapatite as catalyst. Molecules 2010, 15, 813-823.

[8] Srinivas Rao S,; Utility of Schiff's base as a novel catalyst for Knoevenagel condensation: syntheses of benzimidazolylthioacrylonitriles using one-pot, step- wise and tandem fashion. Austin. J. Anal. Pharm. Chem. 2018, 5(1), 1097 (3 pages).

[9] K.Kantharaju,; Prashant B Hiremath. Application of novel, efficient and agro-waste sourced catalyst for Knoevenagel condensation reaction. Ind. J. Chem. 2020, 59B, 258-270.

[10] K Kalaiselvi1,; S Shamala. Eco-friendly and economic method for Knoevenagel condensation by employing natural catalyst of guava leaves (Psidium guajava) Int. J. Academic Res. Develop. 2018, 3, 141-147.

[11] Cláudia O. V,; Cristiane A. H,; Ayres G. D. A green synthesis of $\alpha, \beta$-unsaturated carbonyl compounds from glyceraldehyde acetonide. Quim. Nova. 2011, 34, 617-620.

[12] Turpaev, K.; Ermolenko, M.; Cresteil, T.; Drapier, J.C. Benzylidenemalononitrile compounds as activators of cell resistance to oxidative stress and modulators of multiple signaling pathways. A structure-activity relationship study. Biochem. Pharmacol. 2011, 82, 535-547.

[13] Lee, B.; Moon, K.M.; Lim, J.S.; Park, Y.; Kim, D.H.; Son, S.; Jeong, H.O.; Kim, D.H.; Lee, E. K.; Chung, K.W.; An, H.J.; Chun, P.; Seo, A.Y.; Yang, J.-H.; Lee, B.-S.; Ma, J.Y.; Cho, W.-K.; Moon, H.R.; Chung, H.Y. 2-(3,4-dihydroxybenzylidene)malononitrile as a novel antimelanogenic compound. Oncotarge 2017, 8, 91481-91493.

[14] K. Kantharaju,; Prashant B.H. A green catalytic system for the Knoevenagel condensation using WEPBA. Int. J. Eng. Tech. Sci. Res. 2017, 4, 807-813.

[15] K. Somashekarappa S.;, K. Mohammed Z.; Shivaraj Y. Synthesis of new potential Indole-3-yl derivatives via Knoevenagel condensation. Org. Commun. 2016, 9:4, 119-124.

[16] M.H. Moemeni,; M.A. Amrollahi,; F. Tamaddon. A facile catalyst-free Knoevenagel condensation of pyridinecarbaldehydes and active methylene compounds, Bulgarian Chem. Comm. 2015, 47, 7-12.

[17] Manas, C,; Ajanta M,; Shiho A,; Yoshihiro, H.; Guillaume P. Expeditious reaction of ninhydrin with active methylene compounds on montmorillonite K10 clay. Monatsh. Chem. 2009, 140, 189-197.

[18] Jose, A. C.; Juan, M. C.; Angel, G.; Diego L.; Jose, M. M. Knoevenagel condensation in the heterogeneous phase using AlP04-Al203 as a new catalyst, J. Org. Chem. 1984, 49, 5195-5197.

[19] Shubha, J.; Nagi reddy, B.; Sambasiva rao. K.; Neeliah, G. Microwave assisted synthesis of indole substituted alkenes using Knoevenagel condensation reaction and their antibacterial activity study. E-J. Chem. 2010, 7(S1), S543-S551.

[20] Wang, Q.; Ma, Y.; Zuo, B. Knoevenagel condensation catalyzed by USY zeolite. Synth. Commun. 1997, 27, 4107-4110.

[21] Abaee, M.S.; Mojtahedi, M.M.; Zahedi, M.M.; Khanalizadeh, G. Efficient MgBr2.OEt2 - catalyzed Knoevenagel condensation. Arkivoc 2006, $x v, 48-52$.

[22] Wang, S.; Ren, Z.; Cao, W.; Tong, W. The Knoevenagel condensation of aromatic aldehydes with malononitrile or ethyl cyanoacetate in the presence of CTMAB in water. Synth. Commun. 2001, 31, 673677.

[23] Oskooie, H.A.; Heravi, M.M.; Derikvand, F.; Khorasani, M.; Bamoharram, F.F. On Water: An efficient Knoevenagel condensation using 12-tungstophosphoric acid as a reusable green catalyst. Synth. Commun. 2006, 36, 2819-2823. 
Knoevenagel condensation reaction catalysed by agro-waste extract

[24] Ren, Y.; Cai, C. Knoevenagel condensation of aromatic aldehydes with active methylene compounds using a catalytic amount of iodine and $\mathrm{K}_{2} \mathrm{CO}_{3}$ at room temperature. Synth. Commun. 2007, 37, 22092213.

[25] Keithellakpam, S.; Moiragthem, N.; Laitonjam, W.S. A simple and efficient procedure for the Knoevenagel condensation catalysed by [MeHMTA]BF4 ionic liquid. Int.J.Chem. 2015, 54, 1157-1161 .

[26] Venkat, N.A.; Nagaiah, K. An efficient Knoevenagel condensation catalyzed by $\mathrm{LaCl}_{3} .7 \mathrm{H}_{2} \mathrm{O}$ in heterogeneous medium. Synt. Comm. 2003, 33(21), 3825-3832.

[27] Ramchander,P,; Satyanarayana, B. A solvent free and efficient Knoevenagel condensation; using solid mixed metal oxide $\mathrm{Fe}_{2} \mathrm{O}_{3} / \mathrm{SnO}_{2}$ as heterogeneous catalyst. J.Chem. Chemical Sci. 2017, 7(3), 213-221.

[28] Reddy, B.M.; Patil, M.K.; Rao, K.N.; Reddy, G.K. An easy-to-use heterogeneous promoted zirconia catalyst for Knoevenagel condensation in liquid phase under solvent-free conditions. J Mol. Cat. A: Chemical 2006, 258, 302-307.

[29] Gill, C.; Pandhare, G.; Raut, R.; Gore, V.; Gholap, S. Knoevenagel condensation: A simple and efficient protocol of electrophilic alkenes catalyzed by anhydrous ferric sulphate with remarkable reusability. Bull. Cat. Soc. In, 2008, 7, 153-157.

[30] Gupta, R.; Gupta, M.; Paul, S.; Rajive, G. Silica supported ammonium acetate: an efficient and recyclable heterogeneous catalyst for Knoevenagel condensation between aldehydes or ketones and active methylene group in liquid phase. Bull. Korean Chem. Soc. 2009, 30, 2419-2421

[31] Luan, Y.; Qi, Y.; Gao, H.; Andriamitantsoa, R.S.; Zheng, N.; Wang, G. A general post-synthetic modification approach of amino-tagged metal-organic frameworks to access efficient catalysts for the Knoevenagel condensation reaction. J. Mat. Chem. A, 2015, 3, 17320-17331.

[32] Muralidhar, L.; Girija, C.R. Simple and practical procedure for Knoevenagel condensation under solventfree conditions. J. Saudi Chem. Soc. 2014, 18, 541-544.

[33] Rodrigo, De O. V.; Edson, N. Dos S.; Gabriela, C.;Mauri Sergio, A. P. Use of piperidine and pyrrolidine in Knoevenagel condensation. Org. Med. Chem I.J. 2018, 5(3), 555668. doi: 10.19080/OMCIJ.2018.05. 555668

[34] Suresh, S.P.; Swati, D. J.; Deshmukh, M. B. Ecofriendly and economic method for Knoevenagel condensation by employing natural catalyst, Int. J.Chem. 2013, 52B, 1172-1175.

[35] Yue, C.; Mao, A.; Wei, Y.; Lü, M. Knoevenagel condensation reaction catalyzed by task-specific ionic liquid under solvent-free conditions. Catal. Commun. 2008, 9, 1571-1574.

[36] Rammohan P. Visible light induced Knoevenagel condensation: a clean andefficient protocol using aqueous fruit extract of tamarindus indica as catalyst. Int. J. Adv. Chem. 2014, 2 (1), 27-33.

[37] Saeed, B. Morteza, B. Novel, Efficient, and green Procedure for the Knoevenagel condensation catalyzed by diammonium hydrogen phosphate in water. Synth. Comm. 2006, 36, 2549-2557.

[38] Sarmah, M.; Mondal, M.; Bora, U. Agro-waste extract based solvents: emergence of novel green solvent for the design of sustainable processes in catalysis and organic chemistry. Chem.Select, 2017, 2, 51805188.

[39] Saikia, E.; Bora, S.J.; Chetia, B. $\mathrm{H}_{2} \mathrm{O}_{2}$ in WERSA: an efficient green protocol for ipso-hydroxylation of aryl/heteroarylboronic acid. $R S C A d v$. 2015, 5, 102723-102726.

[40] Shinde, S.; Damate, S.; Morbale, S.; Patil, M.; Patil, S.S. Aegle marmelos in heterocyclization: greener, highly efficient, one-pot three-component protocol for the synthesis of highly functionalized $4 \mathrm{H}$ benzochromenes and 4H-chromenes. RSC Adv. 2017, 7, 7315-7328.

[41] Chia, P.W.; Lim, B.S.; Yong, F.S.J.; Poh, S.-C.; Kan, S.-Y. An efficient synthesis of bisenols in water extract of waste onion peel ash. Environ. Chem. Lett. 2018, 16, 1493-1499.

[42] Laskar, K.; Bhattacharjee, P.; Gohain, M.; Deka, D.; Bora, U. Application of bio-based green heterogeneous catalyst for the synthesis of arylidinemalononitriles. Sustain. Chem. Pharm. 2019, 14, 100181.

[43] Zhongjiao, R.; Weigud, C.; Weiqi T. The Knoevenagel condensation reaction of aromatic aldehydes with malononitrile by grinding in the absence of solvents and catalysts. Synth. Commun. 2002, 32, 3475-3479.

[44] Dewan, A.; Sarmah, M.; Bora, U.; Thakur, J.A. A green protocol for ligand, copper and base free Sonogashira cross-coupling reaction. Tetrahedron Lett. 2016, 57, 3760-3763.

[45] Bagul, S.D.; Rajput, J.D.; Bendre, R.S. Synthesis of 3-carboxycoumarins at room temperature in water extract of banana peels. Environ. Chem. Lett. 2017, 15, 725-731.

[46] Herrmann, W.A.; Kohlpaintner, C.W. Water-soluble ligands, metal complexes, and catalysts: synergism of homogeneous and heterogeneous catalysis. Ang. Chem. Int. Ed. Engl. 1993, 32, 1524-1544

[47] Lu, W.; Chan, T.H. Indium-mediated organometallic reactions in aqueous media. Stereoselectivity in the crotylation of sulfonimines bearing a proximal chelating group. J. Org. Chem. 2001, 66, 3467-3473.

[48] Saikia, B.; Borah, P. A new avenue to the Dakin reaction in $\mathrm{H}_{2} \mathrm{O}_{2}$-WERSA. RSC Adv. 2015, 5, 105583105586. 
Badiger and Kantharaju, Org. Commun. (2021) 14:1 81-91

[49] Sarmah, M.; Dewan, A.; Mondal, M.; Thakur, A. J.; Bora, U. Analysis of the water extract of waste papaya bark ash and its implications as an in situ base in the ligand-free recyclable Suzuki-Miyaura coupling reaction. $R S C A d v$. 2016, 6, 28981-28985.

[50] Ajmal R. B.; Mohd H. N.; Rajendra S. D.; Mohammad S. A. Microwave assisted synthesis of Knoevenagel derivatives using water as green solvent. Curr. Res. Green Sustain. Chem. 2020, 3, 100008 (4 pages).

[51] Umair Ahmed, K.; Imran Ali, H.; Abdul, W.; Muneera Naz, B.; Shoaib M.; Syed Kashif A.; Firdous Imran, A. Synthesis of $\alpha$-cyanoacrylates through Knoevenagel condensation under solvent free conditions and their antimicrobial activity. Int. J. Curr. Res. 2015, 7, 13808-13811.

[52] Franklin S. P.; Ata a. A.; Marwan R. K. Catalyst study of the Knoevenagel condensation. J. Chem. Eng. Data 1963, 8, 597-599.

[53] Kantharaju.K.; Santosh. Y.K.; Microwave accelerated synthesis of 2-Amino-4H-chromenes catalyzed by WELFSA: a green protocol. Chem. Select 2018, 3, 5016- 5024.

[54] Kanagaraj, M.; Shanmugasundaram, K.; Velayutham, S.; Subramaniyan, M.; Murugavel, K. Zn based metal organic framework as a heterogeneous catalyst for $\mathrm{C}-\mathrm{C}$ bond formation reactions. New J. Chem. 2019, 43, 3793-3800.

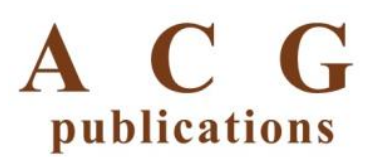

(C) 2021 ACG Publications 